\title{
В.А. Печерский
}

\section{НЕКОТОРЫЕ АСПЕКТЫ ДЕЯТЕЛЬНОСТИ ИСПРАВИТЕЛЬНО-ТРУДОВЫХ УЧРЕЖДЕНИЙ КРАСНОЯРСКОГО КРАЯ В ГОДЫ ВЕЛИКОЙ ОТЕЧЕСТВЕННОЙ ВОЙНЫ}

\begin{abstract}
Рассматриваются вопросы, связанные с функционированием исправительно-трудовых учреждений Красноярского края в военное время. С началом войны был усилен режим содержания заключенных. Ухудшилось снабжение осужденных, а продолжительность рабочего дня была увеличена. Было мобилизовано значительное количество вольнонаемных сотрудников исправительно-трудовых учреждений, вместо них были призваны военнообязанные старших возрастов, не имевшие опыта работы в подобных учреждениях, что привело к ослаблению дисциплины в лагерях и колониях и росту числа побегов заключенных. Ухудшение питания и увеличение продолжительности рабочего дня заключенных приводило к росту заболеваемости и смертности среди контингента.

Ключевые слова: Красноярский край; Великая Отечественная война; исправительно-трудовые учреждения; ГУЛАГ.
\end{abstract}

В годы Великой Отечественной войны исправительно-трудовая система была одной из составляющих экономической жизни страны. Поскольку труд заключенных еще в 1930-е гг. использовался во многих отраслях промышленности, в строительстве и сельском хозяйстве, он продолжал играть важную роль и в экономике военного времени. В том числе и от труда осужденных зависело обеспечение фронта и тыла, поэтому снабжение отбывавших наказание продуктами и промышленными товарами, их отношения с вольнонаемным персоналом лагерей и колоний, состояния производственной базы мест заключения являются актуальными вопросами изучения экономики Советского Союза в военный период.

Деятельность учреждений, подчиненных ГУЛАГу НКВД СССР, вызывает устойчивый интерес у историков в последние годы. Вопросам функционирования исправительно-трудовых учреждений в военное время уделено внимание в монографии Г.М. Ивановой [1].

Медико-санитарное обеспечение осужденных рассматривалось в статьях С.Б. Пономарева, А.Р. Пустовалова и А.А. Черенкова [2], П.В. Виноградова [3] и Е.В. Суверова [4]. Экономическая деятельность учреждений ГУЛАГа была изучена в работе О.В. Хлевнюка [5].

Деятельность исправительно-трудовых учреждений Красноярского края в годы Великой Отечественной войны была исследована в статьях Е.С. Маменковой $[6,7]$.

Уже 22 июня 1941 г. все НКВД, УНКВД, начальники исправительно-трудовых лагерей (ИТЛ) и оперативных отделов лагерей, а также прокуроры союзных и автономных республик, краев, областей и прокуроры ИТЛ получили телеграммы от наркома внутренних дел СССР Л.П. Берии и прокурора СССР В.М. Бочкова, в которых содержался приказ о прекращении освобождения из тюрем, лагерей и колоний «контрреволюционеров, бандитов, рецидивистов и других опасных преступников» [8. Л. 49].

Заключенные указанных категорий, а также находившиеся в заключении советские граждане (немцы и поляки по национальности) и иностранцы должны были быть сосредоточены в особо охраняемых зонах. Осужденные, на которых имелись материалы об антисоветской деятельности, помещались под арест. Переписка с волей не только заключенных, но и спецпоселенцев, прекращалась [Там же].
Охрана лагерей, тюрем и колоний переводилась на военное положение. Запрещались отпуска для всех вольнонаемных сотрудников исправительно-трудовых учреждений. Находившиеся в отпусках отзывались на работу [8. Л. 49]. Тыл рассматривался как продолжение фронта и начинал жить по законам военного времени.

Вместе с этим шел процесс досрочного освобождения заключенных. По инициативе НКВД СССР 12 июля и 24 ноября 1941 г. были изданы указы Президиума Верховного Совета СССР о досрочном освобождении некоторых категорий заключенных, осужденных за прогулы и незначительные должностные и хозяйственные преступления с передачей освобождавшихся призывных возрастов в Красную Армию. Исходя из положений этих указов, по всей стране были освобождены 420 тыс. человек [9. С. 135].

Досрочное освобождение происходило следующим образом: выносилось краткое постановление, утверждавшееся начальником лагеря. Каждое освобождение должно было быть подтверждено прокурором краевой прокуратуры. Военкоматами в места заключения направлялись врачебные комиссии, которые производили медицинский осмотр заключенных призывного возраста. Признанные годными к несению воинской службы после соблюдения всех формальностей выходили на свободу и направлялись в распоряжение военкоматов. Освобождавшиеся несовершеннолетние направлялись к родителям, не имевшие родителей трудоустраивались на различные предприятия [10. Л. 117].

Основной задачей вышеназванных указов было получение пополнения для вооруженных сил. К началу марта 1942 г. из мест заключения в крае из 24863 отбывавших там наказания вышли 6339 человек, или 25,4\%. В распоряжение военкоматов передали 2905 человек - 45,8\% от числа освобожденных. Были осуждены по Указам Президиума Верховного Совета СССР от 10 августа 1940 г. «Об уголовной ответственности за мелкие кражи на производстве и за хулиганство», от 28 декабря 1940 г. «Об ответственности учащихся ремесленных, железнодорожных училищ и школ ФЗО за нарушение дисциплины и за самовольный уход из училища (школы)», и от 9 апреля 1941 г. «Об уголовной ответственности за самовольный проезд в товарных поездах и самоволь- 
ную без надобности остановку поезда стоп-краном», предусматривавших небольшие сроки заключения 243 человека, получивших свободу. 271 человек отбывал наказание за маловажные бытовые преступления. Остальные освобожденные являлись бывшими военнослужащими, женщинами, имевшими несовершеннолетних детей, и инвалидами [10. Л. 117 об.].

Выход на свободу значительного количества заключенных мог спровоцировать всплеск преступности, однако в условиях войны, тем, кто не представлял большую общественную опасность и были осуждены за проступки, которые в другое время и при других обстоятельствах не считались бы преступлениями, государство доверило оружие и большинство из них оправдало доверие.

Убытие значительного количества отбывавших наказание вызвало перебои с рабочей силой в лагерной экономике. Для преодоления нехватки людей к концу января 1942 г. планировалось мобилизовать через райвоенкоматы 5 тыс. мужчин-немцев от 17 до 30 лет, переселенных в Красноярский край из Поволжья [11. Л. 112]. Молодые немцы не подлежали призыву в армию, но обязаны были трудиться в тылу.

Война потребовала усиления дисциплины и бдительности, в том числе и в исправительно-трудовой системе. Места заключения являлись потенциальными источниками дестабилизации особенно опасной в условиях перехода страны на военные рельсы. В соответствии с приказом наркома внутренних дел и прокурора СССР, 23 июня 1941 г. начальник управления Енисейского исправительно-трудового лагеря старший лейтенант госбезопасности Р.П. Филимонов издал собственный приказ «Об усилении охраны и режима содержания заключенных в лагпунктах и колониях» [8. Л. 46].

В приказе от начальников строительства и колоний Енисейлага содержалось требования к руководящим работникам провести оперативные совещания с сотрудниками исправительно-трудовых учреждений, на которых необходимо было обратить внимание всего вольнонаемного состава на усиление и укрепление охраны и режима содержания заключенных, повышение производительности труда, усилить боевую и политическую учебу личного состава военизированной охраны (ВОХР), укреплять воинскую и трудовую дисциплину. Усиление режима содержания должно было выразиться в пересмотре списков на расконвоирование осужденных; из числа отбывавших наказания за бытовые и малозначительные преступления, кому разрешалось передвигаться без конвоя, должно было остаться минимальное количество, необходимое для производства. Списки на бесконвойное движение утверждал лично начальник управления Енисейлага. Заключенные, склонные к побегам, и те, на которых имелись компрометирующие материалы, должны были быть сведены в режимные бригады и выводиться на работу под усиленным конвоем.

Личный состав охраны переводился на военное положение, усиливалась охрана казарм и особенно складов с оружием и боеприпасами. Прекращались очередные отпуска личного состава. Находившиеся в отпусках сотрудники отзывались на работу [Там же].
С 28 июня 1941 г. на основании приказа заместителя наркома внутренних дел В.В. Чернышова колониям и стройкам Енисейлага предписывалось до особого распоряжения увеличить продолжительность рабочего дня заключенных до 12 ч, предоставляя им выходные дни не более 2 раз в месяц. А в том случае, если та или иная промышленная колония получала оборонный заказ, дни отдыха отменялись вовсе и могли быть предоставлены лишь после выполнения программы заказа и не чаще, чем 2 раза в месяц. Питание осужденных осуществлялось прямо на рабочих местах [8. Л. 66].

Исправительно-трудовая система вместе со всей страной начинала жить в соответствии с реалиями военного времени. Многие послабления, допустимые в мирной жизни, в период войны могли привести к серьезным последствиям. Ограничение свободы испытали на себе не только заключенные, но и вольнонаемные сотрудники исправительно-трудовой системы, особенно стрелки ВОХР, которым предстояло трудиться значительно интенсивней, а спрос с них стал гораздо строже.

Режим содержания заключенных особенно усиливался в дни революционных праздников и предшествовавшее им время. 28 октября 1941 г. Р.П. Филимонов отдал приказ по управлению Енисейлага, который открывался следующей преамбулой: «...в дни, когда весь советский народ поднялся на Великую Отечественную войну против озверелых фашистских банд, вероломно напавших на нашу Родину, задачей лагерей и колоний НКВД является полное обеспечение государственной безопасности, обеспечение жесткого режима и порядка в лагере, не допускающего ни одного побега» [Там же. Л. 112].

От вольнонаемного состава и особенно стрелков ВОХР начальник управления требовал дисциплинированности, организованности, политической стойкости. Сотрудники исправительно-трудовых учреждений должны были работать, не считаясь с трудностями, столько сколько требуется «в интересах государственной безопасности и укрепления обороны страны» [Там же]. Лучшим подарком к 24-й годовщине Великой Октябрьской социалистической революции, по мнению старшего лейтенанта Филимонова, было «успешное выполнение каждого задания стрелком, командиром, политработником, сотрудником» [Там же].

Для обеспечения порядка в исправительнотрудовых учреждениях руководители таковых должны были до 3 ноября 1941 г. проверить состояние электроосвещения, сигнализации, связи, отопительных приборов и противопожарных средств. Командирам взводов предписывалось составить план обороны лагеря на случай беспорядков среди заключенных. При взводах устанавливались суточные дежурства из лиц среднего командного состава. В карауле в праздничные и предпраздничные дни находились лучшие бойцы, которых должны были определить политрук взвода и командир караула из партийно-комсомольского актива, ударников и отличников боевой и политической подготовки. С 5 по 10 ноября 1941 г. назначалось дежурное отделение в состав, которого передавался пулеметный расчет [8. Л. 112-112 об.]. 
До 6 ноября 1941 г. необходимо было провести обыск всех заключенных, изъяв запрещенные предметы. Запрещалось их бесконвойное передвижение, а также свидания и прием посылок и передач. Осужденных, находившихся на плохом счету, т.е. склонных к побегу, уличенных в антисоветской агитации, злостных нарушителей режима, хулиганов и отказников от работы изолировали от остальных отбывавших наказание, за ними устанавливалось тщательное наблюдение [8. Л. 112 об].

Подобные меры применялись и в последующие годы. В приказе заместителя начальника управления НКВД по Красноярскому краю подполковника госбезопасности Шустина от 10 апреля 1944 г. содержались не только традиционные положения о проверке освещения и сигнализации, усиления охраны «наиболее важных и опасных в диверсионном отношении объектов (складов с продовольствием, нефтебаз, гараже, мастерских)» [12. Л. 27], переводе личного состава ВОХР на казарменное положение, поголовном обыске заключенных, но и о создании не позднее 28 апреля 1944 г. трехдневного запаса продуктов для отбывавших наказание. Кроме того, запрещались все работы, кроме оборонных и аварийных. Для производства таковых следовало создать бригады из осужденных, в которые не допускались помимо осужденных за «контрреволюционные выступления» и бандитизм признанные виновными в воинских преступлениях и побывавшие на оккупированной территории [Там же].

За случившиеся в праздничные и предпраздничные дни побеги, беспорядки, аварии и другие эпизоды спрос был особенно суров. Партийное руководство края стремилось к тому, чтобы революционные праздники проходили в спокойной обстановке и не омрачались неприятными событиями, для чего в указанные дни должна была быть произведена максимальная изоляция заключенных.

В военное время значительно ухудшилось снабжение контингента продовольствием. Уже в июле 1941 г. на 25\% была сокращена норма выдачи хлеба отбывавшим наказание. Рыбы, мяса, крупы и других продуктов они стали получать на 10\% меньше [6. С. 258]. Много осужденных было эвакуировано из европейской части СССР в Сибирь, что провоцировало скученность в бараках. Вкупе с увеличением рабочего дня и сокращением количества выходных это приводило к истощению отбывавших наказание, следствием чего было снижение трудоспособности и увеличение смертности осужденных. Если в 1940 г. из всех заключенных годных к тяжелому труду (группа «А») было 35,6\%, то к 1 января 1942 г. таких оставалось 19,2\%. Процент годных к среднему труду (группа «Б») за тот же период снизился с 25,2 до 17. При этом количество годных к легкому труду (группа «В») выросло с 15,6 до $38,3 \%$, а инвалидов и ослабленных (без категории) - с 23,6 до 25,5\% [9. С. 138].

В лагпунктах Красноярского исправительнотрудового лагеря на 1 января 1942 г. было 22243 заключенных, из них 633 женщины. К категории «А» принадлежали 4150 человек, «Б» - 6 436, «В» - 7152 , вне категорий - 296 человек, 10 были несовершеннолетними, 4399 - инвалидами. С 1 июля 1941 г. по
1 января 1942 г. в Краслаг прибыл 5751 заключенный, выбыли в другие лагеря - 608, были освобождены - 3007, умерли - 633 [11. Л. 110-111].

По перечисленным выше причинам наиболее многочисленной являлась категория «В». Поскольку основной задачей Краслага была организация лесозаготовок, такое соотношение категорий заключенных значительно затрудняло выполнение производственных планов. Эта проблема была характерной для мест заключения по всей стране, и руководство НКВД было вынуждено предпринять меры для улучшения положения осужденных.

Опираясь на распоряжение НКВД СССР от 2 марта 1942 г., Р.П. Филимонов, к тому времени являвшийся начальником управления исправительнотрудовых лагерей и колоний (УИТЛК) НКВД по Красноярскому краю, 25 марта 1942 г. отдал приказ по вверенному ему ведомству, в котором предписывалось организовать три оздоровительнопрофилактических пункта (ОПП) на 450 коек. Первый такой пункт располагался при строительстве Красноярского гидролизного завода. Он был рассчитан на 300 пациентов и должен был обслуживать контингенты Зыковской, Злобинской и Базаихской колоний массовых работ, Березовской трудовой, Красноярской и Качинской промышленных колоний. Другой пункт на 100 коек организовывался при строительстве Абаканского гидролизного завода, туда доставляли заключенных из Черногорской и Усинской колоний массовых работ, Минусинской промышленной и Ширинской сельскохозяйственной колоний. В рассчитанном на 50 пациентов пункте при строительстве Канского гидролизного завода должны были проходить лечение и восстановление контингенты Канской трудовой и Абанской сельскохозяйственной колоний. Для организации ОПП руководителям строительства указанных предприятий надлежало выделить за счет лагерного жилфонда и отремонтировать в десятидневный срок: директору Красноярского завода Сервилину - 2 барака на 300 коек, Абаканского завода Куликову - 1 барак на 100 коек, Канского завода Тимофееву - 1 барак на 50 коек. Выделенные под пункты бараки, во избежание общения помещенных туда заключенных с общей массой лагерного контингента, следовало отгородить отдельной зоной [12. Л. 27].

Каждый ОПП должен был обслуживать обширную территорию с большим количеством потенциальных пациентов, поэтому количество мест, предусмотренных для размещения больных и истощенных, было явно недостаточным. Нахождение части контингента в более комфортных условиях могло вызвать гнев других осужденных, и во избежание конфликта бараки, определенные под лечебно-восстановительные пункты, отделялись от остальных жилых помещений.

Заключенные часто перебрасывались с места на место, туда, где требовалась рабочая сила. При этом руководители учреждений старались сохранить у себя здоровых осужденных, а больных и истощенных отправить в другие места. Так, начальнику Абаканской колонии массовых работ Курбатову в августе 1942 г. было предписано направить 200 отбывавших наказание на строительство Норильского никелевого ком- 
бината. Согласно распоряжению краевого УИТЛК, отправке подлежали исключительно физически здоровые заключенные, годные к работе в районах Крайнего Севера, однако 24 августа 1942 г. из прибывших в первой партии 100 осужденных врачебная комиссия Норильского ИТЛ не приняла 53 человека по состоянию здоровья. Из числа забракованных 24 были больны пеллагрой, 5 оказались инвалидами. 10 человек норильские врачи были вынуждены поместить в стационар. Были признаны годными к легкому физическому труду с пониженной нормой выработки (от 50 до 70\% от общепринятой) 16 прибывших из Хакасии, 13 являлись ограниченно годными. Подобные вещи руководство Абаканской колонии проделывало не впервые, 15 августа 1942 г. из 40 заключенных, направленных оттуда на строительство моста через Енисей, 10 оказались нетрудоспособными и были помещены в ОПП. За направление на строительство нетрудоспособного контингента Курбатов был арестован на 10 сут с исполнением служебных обязанностей. Начальник санитарной части Бусоедов и старший инспектор уголовного розыска колонии Лапутин были помещены под арест на 5 сут без исполнения служебных обязанностей каждый. Отбывали наказание они при Хакасском областном управлении НКВД [13. Л. 56-56 об.].

Отправка в другое место сотен физически здоровых заключенных могла поставить под угрозу выполнение производственных планов Абаканской колонией, поэтому ее руководство старалось избежать потери такого количества рабочей силы даже ценой нарушения приказа сверху. Однако Норильский комбинат с 1941 г. входил в список ударных сверхлимитных строек НКВД, где работы должны были производиться за счет других объектов [1. С. 234]. Предприятие имело оборонное значение, и содействовать его строительству надлежало всеми силами.

Положение осужденных во многом зависело от персонала ИТУ. Отношения заключенных и вольнонаемных работников, в особенности охраны, характеризовались диалектическим законом единства и борьбы противоположностей. Часто интересы находившихся по разные стороны колючей проволоки совпадали. От состояния контингента зависело выполнение производственных планов, поэтому лагерное начальство, с одной стороны, было заинтересовано в хорошем снабжении отбывавших наказание, их лечении, моральном состоянии. С другой стороны, стремление заключенных к свободе, порождавшее побеги, никак не могло устроить персонал мест заключения.

Состав сотрудников тех или иных ИТУ отражал нужды соответствовавшего учреждения. Так, к началу войны в Красноярской промышленной колонии Енисейского ИТЛ НКВД трудились 99 вольнонаемных сотрудников. Управлением учреждения занимались 5 человек: начальник колонии И.А. Кучец, получавший оклад в размере 800 руб., комендант В.Ф. Прокошин с окладом 500 руб. и др. В бухгалтерии работали 4 человека, главный бухгалтер В.В. Лапин получал 800 руб. В плановой части трудились 7 человек, снабжением занимались 4 сотрудника. В санитарной части трудились 6 сотрудников (начальник, фельд- шер, зубной врач и санитарки). В гараже работали 5 человек - 1 заведующий, остальные шоферы; водным транспортом занимались 2 человека; в пожарной части трудились 6 человек. В подсобном хозяйстве было задействованы 2 вольнонаемных сотрудника рабочий свинарника и возчик хлеба [8. Л. 54-55].

Руководили производством в колонии главный инженер П.П. Воскресенский, его оклад составлял 1000 руб., и начальник мебельного производства В.М. Емельченко, получавший 800 руб. В производственной части работали 4 человека, в мастерских -7 . В охране служили 29 человек. Командир взвода И.Т. Жандаров получал 600 руб., зам. командира по политической части С.Д. Кукуюк - 600 руб., помощник командира взвода П.Ф. Гультяев - 350 руб., командиры отделений Л.С. Карелин, П.К. Евтюшенко, И.В. Бухарь - по 300 руб., рядовые стрелки ВОХР зарабатывали по 230 руб. В других частях трудилось 16 человек [Там же. Л. 55].

Таким образом, вольнонаемные сотрудники занимали в колонии должности, требовавшие достаточной квалификации. В их ведении были управление производством, транспорт, пожаротушение. Это были те ответственные должности, которые нельзя было доверить осужденным. Недоверием к контингенту объяснялся и наем в подсобное хозяйство рабочего свинарника и возчика хлеба. На этих местах, не требовалось особых умений, но было слишком велико искушение похитить продукты.

При средней зарплате в 1940 г. в целом по народному хозяйству СССР в 33,1 руб., и при 69,6 руб. инженерно-технических работников в частности [14. С. 350], служба на руководящих должностях в ИТУ приносила достаточно высокий доход замещавшим их лицам. Значение производства для данного учреждения определялось тем, что наиболее высокооплачиваемым сотрудником был не начальник колонии, а главный инженер, а начальник мебельного производства получал столько же, сколько руководитель подразделения. Эти должности требовали определенного уровня образования, опыта работы и предусматривали высокую степень ответственности, что выражалось в размере оклада.

Обстоятельства военного времени внесли серьезные изменения в состав персонала ИТУ. Огромные потери в первые месяцы войны заставили руководство страны искать резервы для пополнения вооруженных сил. 15 сентября 1941 г. было издано Постановление Государственного Комитета обороны «О призыве военнообязанных, пользующихся отсрочками по мобилизации, и граждан 1922 года рождения», предусматривавшего, в числе прочих, призыв работников НКВД [15. Л. 127-129].

В соответствии с приказами Наркомата Обороны от 15 сентября 1941 г. и НКВД от 19 сентября 1941 г., изданными на основании вышеупомянутого Постановления ГКО в ряды РККА подлежали призыву военнообязанные рядового и младшего начальствующего состава запаса РККА, работавшие в органах НКВД и имевшие отсрочку от призыва, т.е. забронированные и состоявшие на спецучете. Под мобилизацию попадали $25 \%$ от общего числа забронированных рядовых 
и сержантов запаса Красной Армии, работавших в подразделениях НКВД, включая ВОХР. Половина из них должна была быть призвана к 15 октября 1941 г., следующие к 15 ноября 1941 г. При этом от призыва освобождались забронированные сотрудники НКВД, являвшиеся руководителями предприятий и учреждений, инженерно-техническими работниками, мастерами и квалифицированными рабочими с 6-го разряда и выше. Оставались в тылу также занимавшие в органах НКВД должности среднего и старшего начальствующего состава и проводники служебнорозыскных собак. Для исполнения данных нормативных правовых актов заместитель начальника управления Енисейлага М.М. Ларионов 24 сентября 1941 г. отдал приказ подчиненным ему ИТУ немедленно связаться с местными райвоенкоматами и начать персональный отбор сотрудников, подлежавших призыву. Одновременно с этим следовало приступить к отбору лиц из запаса РККА старших возрастов, которых через военкоматы надлежало направить в распоряжение НКВД взамен призванных. Приступить к работе новые сотрудники должны были не позднее, чем за 5 дней до момента призыва, первая очередь к 10 октября 1941 г., вторая к 10 ноября 1941 г. Отобранных на замену мобилизованным сотрудникам ИТУ следовало тщательно проверить как на предмет их деловых качеств, так и на наличие судимости, социального происхождения и предыдущей трудовой деятельности. С кандидатами на открывавшиеся вакансии должно было быть проведено собеседование, их документы должны были быть тщательно проверены, проверкой надлежало затронуть районное отделение НКВД и прежнее место работы будущего сотрудника [16. Л. 28-29].

Мобилизация работников исправительно-трудовых учреждений рассчитывалась таким образом, чтобы основным контингентом призванных были рядовые стрелки и младшие командиры ВОХР, т.е. молодые мужчины, умевшие обращаться с оружием. Боеспособность охраны не должна была пострадать в результате призыва, поэтому убытие сотрудников проходило в два этапа, и некоторое время параллельно с мобилизованными служили новички.

Многие сотрудники исправительно-трудовой системы уходили в армию добровольно, поэтому число покинувших ИТУ края было более многочисленным, нежели предусматривалось приказами НКО и НКВД. Так, во втором полугодии 1941 г. из учреждений Краслага выбыли в РККА 1397 человек, что составляло около 40\% всего состава вольнонаемных рабочих и служащих данного ИТЛ, в том числе из охраны 706 человек, или 50\% личного состава ВОХР. Из тех, кто добровольно или по мобилизации становились фронтовиками, был 31 член ВКП(б) и 32 кандидата в партию, что составляло $27 \%$ всей численности парторганизации Краслага. Комсомольцев было 34, или 50\% состава комсомольской организации [11. Л. 106].

Несмотря на освобождение от мобилизации тех сотрудников ИТУ, которые являлись руководителями предприятий и учреждений, инженерно-техническими работниками, мастерами и квалифицированными рабочими из Краслага во второй половине 1941 г. выбыло в РККА достаточно много специалистов лесоза- готовок: трактористов, шоферов, механиков, что создало большие трудности в работе автотранспортного парка. Для замены ушедших в армию специалистов силами данного ИТЛ были организованы курсы продолжительностью 2-3 месяца, к концу 1941 г. 31 выпускник этих курсов работал мастерами лесозаготовок, из них 26 женщины; трактористами и шоферами - 40, из них 11 женщин. Всего из вольнонаемных работников лагеря через курсы прошли 95 человек, многие из них были женщины - жены сотрудников, ушедших в РККА. Выпускники краткосрочных курсов не обладали достаточной квалификацией для выполнения служебных обязанностей, что сказывалось на работе производственных частей [11. Л. 107].

Менее квалифицированными были также новые охранники исправительно-трудовых учреждений. Несмотря на тщательную проверку, которой должны были быть подвергнуты вновь принятые на службу, их подготовка оставляла желать лучшего.

Слабость кадрового состава ИТУ, пришедшего на смену мобилизованным, усугублялась ухудшением их вооружения. У охраны Краслага на нужды РККА были изъяты винтовки российского производства, взамен в августе 1941 г. ВОХР получила 415 японских винтовок, однако патронов к новому оружию у стрелков не было до конца 1941 г. [11. Л. 112].

Эти факторы отрицательным образом сказывались на деятельности исправительно-трудовых учреждений, что выражалось в росте числа побегов заключенных, случившихся по вине сотрудников охраны. Так, 29 июля 1942 г. при этапировании осужденных из Красноярской тюрьмы бежал заключенный по фамилии Пинегин. Данный этап состоял из 22 отбывавших наказание и охранялся 5 конвоирами. Начальник конвоя В.П. Белкин разрешил двоим бойцам конвоя уйти по личным делам, а вскоре удалился сам, оставив за старшего стрелка В.Ф. Фролова. Пинегин воспользовался ослаблением конвоя и скрылся. За безответственное отношение к выполнению служебных обязанностей Белкин был арестован на 10 суток, а Фролов на 5 , с удержанием с каждого $25 \%$ суточной зарплаты за каждые сутки ареста [13. Л. 52].

Действия Белкина, оставившего двоих стрелков против 22 заключенных, могли привести и к более серьезным последствиям, чем побег одного осужденного, поэтому наказание для начальника конвоя выглядело достаточно мягким.

Побеги из Базайской колонии массовых работ были обыденным явлением. За первые 3 квартала 1942 г. оттуда бежали 76 человек. Расследование, проведенное особой инспекцией краевого управления НКВД, показало, что стрелки ВОХР в этой колонии нарушали уставы конвойной и караульной службы, систематически пьянствовали вместе с заключенными, отпускали осужденных без охраны в населенные пункты и на частные квартиры. При этом условия содержания отбывавших наказание находились в неудовлетворительном состоянии, инспекция отметила завшивленность контингента, плохое питание, недостаток одежды и обуви. Следствием этого были высокая заболеваемость и смертность заключенных. За первые 9 месяцев 1942 г. в колонии умерли 155 человек. 
Бегство из этого учреждения провоцировал и произвол, который охрана допускала в отношении осужденных. Имели место случаи, когда охранники избивали отбывавших наказание, склоняли женщин-заключенных к сожительству, незаконно применяли оружие. Так, 26 июля 1942 г. стрелок Варлаков беспричинно выстрелил из винтовки и ранил заключенную Рытникову, за что был подвергнут аресту сроком на 5 суток.

Вопиющий случай произошел в колонии 29 августа 1942 г. В тот день стрелки И.А. Ефимов и В.Г. Лысков охраняли группу осужденных, работавших на угольном складе. По разрешению охранников заключенные Грачев, Светличный и Иванов взяли из стоявшей на складе цистерны ведро спирта, которое было распито совместно работниками колонии и представителями контингента. Во время попойки Грачев бежал. Не добившись от других осужденных ответа об обстоятельствах побега, Ефимов избил прикладом винтовки бригадира заключенных Кравцова, а Лысков расстрелял его. Оба охранника были преданы суду военного трибунала по обвинению в убийстве при особо отягчающих обстоятельствах.

Ответственность за такое положение дел была возложена на руководство Базайской колонии. Приказом по управлению НКВД Красноярского края от 19 ноября 1942 г. начальник колонии Ф.А. Торянский был подвергнут дисциплинарному аресту на 10 суток. Поскольку ранее Федор Артемьевич подвергался подобному наказанию, он был предупрежден, что если в течение месяца не наладит работу вверенного ему учреждения, то будет уволен из органов внутренних дел и отдан под суд. Комендант колонии Кочергин за плохую работу, систематическое пьянство и нарушение трудовой дисциплины был снят с должности [13. Л. 71-71 об.].

Базайская колония являла собой пример острого дефицита кадров, особенно затронувший рядовой состав ВОХР. Заменить не справлявшихся со своими обязанностями сотрудников в условиях войны было сложно, поэтому совершивших преступления привлекали лишь к дисциплинарной ответственности, суду же предавались лишь те, кто был виновен в наиболее тяжких деяниях.

В дальнейшем количество побегов не сокращалось. С 1 января по 20 июня 1944 г. из лагерных подразделений и колоний края бежали 85 заключенных, задержаны были до 20 июня 1944 г. 67 человек. В мае 1944 г. бежали 32 человека, к 20 июня 1944 г. задержан был 21. За первые 20 дней июня 1944 г. совершили побег 15 человек, были задержаны 15. На 20 июня 1944 г. оставалось в бегах 18 осужденных. Руководство исправительно-трудовыми учреждениями объясняло такое положение тем, что «некоторые руководители лагподразделений и колоний продолжают игнорировать приказы и директивы НКВД СССР и краевого управления в деле усиления режима и охраны. Допускаются сон на посту, преступные связи с заключенными, преступно-халатное отношение к исполнению своих обязанностей как работников ВОХР, так и начсостава» [12. Л. 65].

Возможности для улучшения положения с побегами заключенных, количество которых особенно возрастало весной и летом, были крайне ограничены.
Притока квалифицированных кадров в военное время ожидать не приходилось, а ротации личного состава ВОХР продолжались из-за призыва стрелков, а с 1944 г. еще и переброски части охранников в освобожденные от оккупации области для укомплектования создававшихся там ИТУ.

Кадровые проблемы являлись одной из основных причин трудностей в решении главной задачи, стоявшей перед исправительно-трудовыми учреждениями в годы войны - выполнении производственных планов.

Как отмечают В.А. Пронько и В.Н. Земсков, «если в мирное время основной продукцией промышленных колоний ГУЛАГа являлись предметы ширпотреба, то с первых дней войны ГУЛАГ организовал на своих предприятиях выполнение заказов для нужд фронта» [9. С. 143].

Перестроить производство на военный лад было сложно, и государственные задания по оборонной продукции в первые месяцы войны не выполнялись. В ноябре 1941 г. Канская промышленная колония задание по изготовлению деревянной тары для боеприпасов (спецукупорки) выполнила только на 20,4\%, Минусинская - на 65,6\%, Березовская - на 70,1\%. За первую декаду декабря 1941 г. Канская колония не изготовила ни одного комплекта спецукупорки, Минусинская выполнила план за тот же срок на 12,8\%, Березовская - на 15,5\% [8. Л. 132-133].

Освоить выпуск нового вида продукции при мобилизации части технического персонала и предельно сжатых сроках было непросто, но вышестоящее руководство не хотело и могло войти в положение руководителей колоний, начальник УНКВД по Красноярскому краю майор госбезопасности И.П. Семенов обвинял их в том, что работа вверенных им ИТУ не была подчинена интересам фронта, а сами они «проявили самоустраненность, не приняли решительных мер в начале и середине ноября к немедленной перестройке работы на военные рельсы» [Там же. Л. 133].

В вину начальникам колоний вменялось нерациональное использование электроэнергии, которая вместо того, чтобы употребляться на производстве, использовалась для освещения частных квартир. Недостаточно, по мнению майора Семенова, применялся транспорт, был плохо организован труд в бригадах. Борьбу с недостатками в работе колоний начальник краевого УНКВД осуществлял, оказывая давление на руководителей учреждений. Своим приказом он объявил начальнику Канской колонии М.М. Ионову выговор, предупредив его о суровом наказании в случае непринятия мер, обеспечивавших выполнение плана по производству спецукупорки на декабрь 1941 г. Такие же предупреждения получили начальники Минусинской и Березовской колоний Д.Н. Вершинин и И.Н. Кочеров. Особое предупреждение получили начальник промышленного отдела УИТЛК УНКВД Красноярского края Побоев и его заместитель Чепурнов, их уведомили о том, «что их работа в УИТЛ УНКВД Красноярского края будет в прямой зависимости от выполнения промколониями к 1 января 1942 г. программы спецукупорки на декабрь» [8. Л. 134-135].

Побоеву и Чепурнову предписывалось организовать живое руководство и оказание практической по- 
мощи колониям, систематически выезжая туда. Вышеперечисленные лица были дополнительно предупреждены о том, что «если они не выполнят декабрьского задания по спецукупорке, то это невыполнение будет рассматриваться как срыв боевого задания фронта» [8. Л. 136].

В тексте приказа не предлагалось никаких конкретных мер для своевременного выполнения особо важного задания оборонного значения. Изыскание ресурсов, за счет которых предполагалось выполнить план, было личным делом начальников колоний и их непосредственных руководителей.

За первый квартал 1944 г. трудовые и воспитательные колонии края выполнили план производства боеприпасов на 108\%, по производству спецукупорки - на 86,5\%, по отгрузке спецукупорки - на $62 \%$. Канская трудовая колония за этот период произвела $130 \%$ от плана тары для боеприпасов, Красноярская трудовая воспитательная колония план по изготовлению и отгрузке боеприпасов выполнила на 108\%. При этом Березовская трудовая колония план изготовления спецукупорки за первый квартал 1944 г. исполнила лишь на 69,4\% [12. Л. 61].

Таким образом, увеличить производство боеприпасов и тары для них удалось за счет отдельных ИТУ. Некоторые колонии и в завершающий период войны не сумели наладить столь важный участок работы. Ликвидировать дефицит ресурсов и специалистов удалось не везде.

Наиболее острой была транспортная проблема, она сохраняла актуальность и в последующие годы. Так, на 1 декабря 1944 г. на складах Канской трудовой колонии скопилось 16 тыс. комплектов спецукупорки, которую не удавалось отгрузить потребителям [17. Л. 38].

Несколько лучше обстояло дело с заготовкой и обработкой древесины. Канский лагерный пункт Краслага выполнил производственную программу по шпалопилению за второе полугодие 1941 г. на 257\%, по лесопилению - на 188\%, сплаву - на 103\%. В Нижне-Ингашском лагпункте показатели за аналогичный период выражались в следующих цифрах: шпалопиление - 103,2\%, лесопиление - $106 \%$, сплав был закончен досрочно. Однако и здесь отдельные учреждения не справились с возложенными на них задачами. Нижне-Пойменский лагпункт государственный план по заготовке древесины выполнил на 95,6\%, вывозки древесины - на 87,6\%, шпалопиления - на $85 \%$, лесопиления - на 68\%. Поскольку Нижняя Пойма должна была выполнить 46\% всего производственного плана Краслага, лагерь сорвал выполнение производственных программ [11. Л. 104-105].

В других лагерных подразделениях края планы по заготовке древесины находились под угрозой срыва. За первые два месяца 1942 г. ни одна из промышленных колоний, подчиненных краевому УИТЛК, не выполнила план по производству круглого леса. Если Березовская колония в январе-феврале 1942 г. выполнила план лесозаготовок на 70,3\%, Минусинская - на $83,6 \%$, то Красноярская лишь на 44,8\% [13. Л. 23].

Заготавливавшийся перечисленными колониями лес являлся сырьем для спецпродукции, старший лей- тенант Филимонов предупреждал начальников учреждений о том, что «срыв плана лесозаготовок является преступлением перед Родиной и виновные в срыве плана должны понести суровые наказания» [Там же].

Помимо взысканий и угроз таковых в отношении начальников промколоний Р.П. Филимонов в своем приказе от 24 марта 1942 г. предписал Побоеву оказать им практическую помощь в выполнении плана лесозаготовок, разработав график сплава древесины. Начальнику отдела снабжения УИТЛК Лорицу надлежало обеспечить занятых на лесозаготовках рабочих обмундированием, продовольствием и торговым фондом. Транспортный отдел должен был обеспечить колонии необходимым инструментом для проведения лесозаготовок и снастями для сплава [Там же. Л. 23-24].

Р.П. Филимонов, руководивший исправительнотрудовыми учреждениями, разбирался в специфике их деятельности лучше своего непосредственного начальника и поэтому понимал, что одними репрессиями нельзя достигнуть нужного результата. Недостаток в рабочем инвентаре, продовольствии, одежде, невозможность закупить нужные товары не могли исправить карательные меры.

Проблемы с вывозом готовой продукции были вызваны несовершенством транспорта в лагерях и колониях. В ИТУ использовался преимущественно гужевой транспорт, при этом содержание, уход за лошадьми и их кормление были организованы плохо, следствием чего были падеж, выбраковка, потеря работоспособности и простой животных. За первые 5 месяцев 1943 г. в исправительно-трудовых учреждениях края простой лошадей выражался в 14279 конеднях. В Ширинской сельскохозяйственной колонии за этот период было потеряно 924 конедня из-за травматического повреждения лошадей, 830 - вследствие прочих заболеваний. В Качинской колонии в результате травм животных было потеряно 592 конедня [18. Л. 55].

Руководство колоний не уделяло должного внимания содержанию лошадей, потому что все силы были брошены на организацию производства и предотвращение побегов заключенных. Сказывались здесь дефицит кормов и нехватка ветеринаров.

На фоне плохого состояния лошадей, в ИТУ края достаточно успешно развивалось сельскохозяйственное производство. Учреждения Краслага во втором полугодии 1941 г. перевыполнили план по развитию животноводства. По крупному рогатому скоту план был выполнен на $149 \%$, по свинопоголовью - на $150 \%$ [11. Л. 109].

В 1942 г. сельскохозяйственные колонии и подсобные хозяйства УИТЛК края сумели расширить посевные площади, увеличить поголовье скота, обеспечить лагеря овощами и картофелем, создать новую для краевых ИТУ отрасль сельского хозяйства - птицеводство. В результате сельскохозяйственные предприятия управления исправительно-трудовых лагерей и колоний края заняли третье место в социалистическом соревновании в системе НКВД СССР. За выполнение условий соцсоревнования, увеличение площади посева зерновых, овощей и картофеля, за высокие 
показатели по животноводству Л.П. Берия наградил управление грамотой НКВД СССР и денежной премией в сумме 15 тыс. руб. Приказом И.П. Семенова Ширинской сельскохозяйственной колонии УИТЛК было вручено переходящее Красное знамя УИТЛК края с формулировкой: «За лучшие показатели по растениеводству и животноводству, за полное сохранение молодняка, крупного рогатого скота и жеребят» [18. Л. 6].

Часть сельскохозяйственной продукции, производимой в местах лишения свободы, шла на нужды заключенных, что делало их заинтересованными в результатах своего труда. Большинство осужденных были деревенскими жителями, и крестьянский труд был для них привычен, что и объясняет успехи этого вида производства в лагерях и колониях края.

Исправительно-трудовые учреждения переживали вместе со всей страной трудности военного времени.
Выражалось это прежде всего в том, что при меньшем количестве потребляемых калорий трудовая нагрузка на заключенных значительно выросла. Все это вело к истощению и болезням осужденных и, в конце концов, потери их трудоспособности.

Положение контингента усугублялось сложными взаимоотношениями с охраной, с одной стороны, нередки были случаи произвола охранников в отношении заключенных, с другой - панибратства представителей администрации и отбывавших наказание. Подобные аномии провоцировали побеги осужденных и затрудняли выполнение производственных планов подразделениями УИТЛК края. Несмотря на все перечисленные проблемы, исправительно-трудовые учреждения внесли свой вклад в Победу. Сотни тысяч бывших заключенных и вольнонаемных сотрудников лагерей и колоний вместе сражались на фронтах, а остававшиеся в местах заключения трудились в тылу.

\section{ЛИТЕРАТУРА}

1. Иванова Г.М. История ГУЛАГа: 1918-1958. М. : Полит. энциклопедия, 2015. 415 с.

2. Пономарев С.Б., Пустовалов А.Р., Черенков А.А. Организация медико-санитарного обеспечения осужденных в годы Великой Отечественной войны // Ведомости уголовно-исполнительной системы. 2012. № 8. С. 24-28.

3. Виноградов П.В. Социально-бытовые условия содержания заключенных в годы Великой Отечественной войны // Уголовно-исполни-тельная система в годы Великой Отечественной войны : сб. материалов науч.-практ. конф., посвящ. 68-й годовщине Победы в Великой Отечественной войне (г. Новокузнецк, 26 апреля 2013 г.). Новокузнецк : ФКОУ ВПО Кузбасский институт ФСИН России, 2013. С. 18-21.

4. Суверов Е.В. К вопросу о режиме содержания заключенных в местах лишения свободы в Западной Сибири во время Великой Отечественной войны // Вестник Томского государственного университета. История. 2015. № 1 (33). С. $29-33$.

5. Хлевнюк О. В. Экономика ОГПУ-НКВД-МВД СССР в 30-50-е годы ХХ в.: Проблемы и источники // Исторические записки. Вып. 5 (123). М. : Наука, 2002. С. 43-69.

6. Маменкова Е.С. Продовольственное снабжение заключенных Краснояского ИТЛ в 1941-1945 гг. // Вестник Красноярского государственного педагогического университета им. В.П. Астафьева. 2011. № 2. С. 258-263.

7. Маменкова Е.С. Красноярский ИТЛ НКВД в годы Великой Отечественной войны (1941-1945 гг.) // Вестник Кемеровского государственного университета 2016. № 1 (65). С. 19-23.

8. Государственный архив Красноярского края (далее ГАКК). Ф. Р-1433. Оп. 1. Д. 8.

9. Пронько В.А., Земсков В.Н. Вклад заключенных ГУЛАГа в Победу в Великой Отечественной войне // Новая и новейшая история. 1996. № 5. C. 131-151.

10. ГАКК. Ф. П-26. ОП. 3. Д. 290.

11. ГАКК. Ф. П-26. ОП. 3. Д. 151.

12. ГАКК. Ф. Р-1433. Оп. 1. Д. 21.

13. ГАКК. Ф. Р-1433. Оп. 1. Д. 9.

14. Народное хозяйство СССР. 1922-1972 гг. Юбилейный статистический ежегодник. М. : Статистика, 1972.848 с.

15. Российский государственный архив социально-политической истории). Ф. 644. Оп. 1. Д. 7.

16. ГАКК. Ф. Р-1433. ОП. 1. Д. 7.

17. ГАКК. Ф. Р-1433. ОП. 1. Д. 20.

18. ГАКК. Ф. Р-1433. ОП. 1. Д. 12.

Статья представлена научной редакцией «История» 28 ноября 2017 г.

\section{SOME ASPECTS OF THE ACTIVITIES OF CORRECTIONAL LABOR INSTITUTIONS OF KRASNOYARSK KRAI} DURING THE GREAT PATRIOTIC WAR

Vestnik Tomskogo gosudarstvennogo universiteta - Tomsk State University Journal, 2018, 428, 151-159.

DOI: $10.17223 / 15617793 / 428 / 20$

Vladimir A. Pecherskiy, Khakassian Research Institute of Language, Literature and History (Abakan, Russian Federation). E-mail: volody75.75@mail.ru

Keywords: Krasnoyarsk Region; Great Patriotic War; correctional labor institutions; the Gulag.

The aim of this article is to examine various aspects of life of correctional labor institutions of the region during the Great Patriotic War. The source base of the research is documents from the State Archive of Krasnoyarsk Krai, scientific articles introduced into scientific circulation and published for the first time and monographs. At the beginning of the war the release of prisoners convicted of "counterrevolutionary crimes", banditry and other serious crimes and those having served the sentence was suspended. Those convicted for minor acts were released early, in the autumn of 1941, to replenish the army. By the beginning of March 1942, out of 24,863 people serving their sentences 6,339 people or $25.4 \%$ were released from prison in the region. 2,905 people, $45.8 \%$ of the number of the released, were assigned to the military registration and enlistment office. A significant number of the civilian staff of camps and colonies, especially guards who enjoyed the right of deferment from the draft, were also mobilized. $25 \%$ of privates and sergeants of the reserve of the Red Army working in the People's Commissariat of Internal Affairs were subject to the draft, but the number of mobilized employees of correctional labor institutions was much larger, as many of them went to the front voluntarily. Thus, in the second half of 1941, 1,397 people went to the Workers' and Peasants' Red Army from the institutions of Kraslag, which amounted to about $40 \%$ of the total staff of civilian workers and employees of this correctional labor facility, 
including 706 security officers, or 50\% of the staff of the Paramilitary Security Service. For those in prison the detention regime was tightened; their food and manufactured goods supply worsened significantly. Moreover, the working day for those in prison was increased up to 12 hours, days off were given not more than twice a month; when fulfilling defense tasks, days off were cancelled at all. All this led to the depletion of people serving sentences, their growing morbidity and mortality. In March 1942, three health and prevention centers were organized in the region to restore the strength and health of prisoners. In extremely severe conditions the camp economy switched to the production of goods necessary for the acting army. The camps and colonies of the region started producing ammunition and wooden containers for it (specialized empties). The production of defense products was constantly behind the schedule. Difficulties with the implementation of tasks for timber logging arose as well. The correctional labor facility of the region was much more successful in agricultural production ranking third in the socialist competition in the system of the USSR People's Commissariat of Internal Affairs in 1942. The author comes to a conclusion that fewer calories consumed by prisoners in the war time and a significant increase in their workload were the reason for the failure of state plans, exhaustion of prisoners, increase of their morbidity.

\section{REFERENCES}

1. Ivanova, G.M. (2015) Istoriya GULAGa: 1918-1958 [History of the Gulag: 1918-1958]. Moscow: Polit. entsiklopediya.

2. Ponomarev, S.B., Pustovalov, A.R. \& Cherenkov, A.A. (2012) Organizatsiya mediko-sanitarnogo obespecheniya osuzhdennykh v gody Velikoy Otechestvennoy voyny [The organization of medical and sanitary support for convicts during the Great Patriotic War]. Vedomosti ugolovnoispolnitel'noy sistemy. 8. pp. 24-28.

3. Vinogradov, P.V. (2013) [Social and living conditions of prisoners during the Great Patriotic War]. Ugolovno-ispolni-tel'naya sistema v gody Velikoy Otechestvennoy voyny [Penal system in the years of the Great Patriotic War]. Proceedings of the conference dedicated to the 68th anniversary of the victory in the Great Patriotic War. Novokuznetsk. 26 April 2013. Novokuznetsk: Kuzbass Institute of the Federal Penitentiary Service of Russia. pp. 18-21. (In Russian).

4. Suverov, E.V. (2015) To the question of detention regime of prisoners in imprisonment places in West Siberia during the Great Patriotic War. Vestnik Tomskogo gosudarstvennogo universiteta. Istoriya - Tomsk State University Journal of History. 1 (33). pp. 29-33. (In Russian).

5. Khlevnyuk, O. V. (2002) Ekonomika OGPU-NKVD-MVD SSSR v 30-50-e gody XX v.: Problemy i istochniki [Economics of the OGPU-NKVDMVD USSR in the 1930s-1950s: Problems and Sources]. Istoricheskie zapiski. 5 (123). pp. $43-69$.

6. Mamenkova, E.S. (2011) Prodovol'stvennoe snabzhenie zaklyuchennykh Krasnoyaskogo ITL v 1941-1945 gg. [Food supply for prisoners of Krasnoyarsk forced labour camp in 1941-1945]. Vestnik Krasnoyarskogo gosudarstvennogo pedagogicheskogo universiteta im. V.P. Astaf'eva Bulletin of KSPU. 2. pp. 258-263.

7. Mamenkova, E.S. (2016) Krasnoyarsk forced labour camp of the USSR National Commissariat of Military Affairs during the Great Patriotic War (1941-1945). Vestnik Kemerovskogo gosudarstvennogo universiteta - Bulletin of the Kemerovo State University. 1 (65). pp. 19-23. DOI: http://dx.doi.org/10.21603/2078-8975-2016-1-19-23

8. State Archive of Krasnoyarsk Krai (GAKK). Fund R-1433. List 1. File 8. (In Russian).

9. Pron'ko, V.A. \& Zemskov, V.N. (1996) Vklad zaklyuchennykh GULAGa v Pobedu v Velikoy Otechestvennoy voyne [Contribution of Gulag prisoners to the victory in the Great Patriotic War]. Novaya i noveyshaya istoriya. 5. pp. 131-151.

10. State Archive of Krasnoyarsk Krai (GAKK). Fund P-26. List 3. File 290. (In Russian).

11. State Archive of Krasnoyarsk Krai (GAKK). Fund P-26. List 3. File 151. (In Russian).

12. State Archive of Krasnoyarsk Krai (GAKK). Fund R-1433. List 1. File 21. (In Russian).

13. State Archive of Krasnoyarsk Krai (GAKK). Fund R-1433. List 1. File 9. (In Russian).

14. Statistika. (1972) Narodnoe khozyaystvo SSSR. 1922-1972 gg. Yubileynyy statisticheskiy ezhegodnik [National economy of the USSR. 1922-1972 anniversary statistical yearbook]. Moscow: Statistika.

15. Russian State Archive of Social and Political History. Fund 644. List 1. File 7. (In Russian).

16. State Archive of Krasnoyarsk Krai (GAKK). Fund R-1433. List 1. File 7. (In Russian).

17. State Archive of Krasnoyarsk Krai (GAKK). Fund R-1433. List 1. File 20. (In Russian).

18. State Archive of Krasnoyarsk Krai (GAKK). Fund R-1433. List 1. File 12. (In Russian). 